\title{
SMALL GEOTHERMAL ELECTRIC SYSTEMS FOR
}

\author{
REMOTE POWERING
}

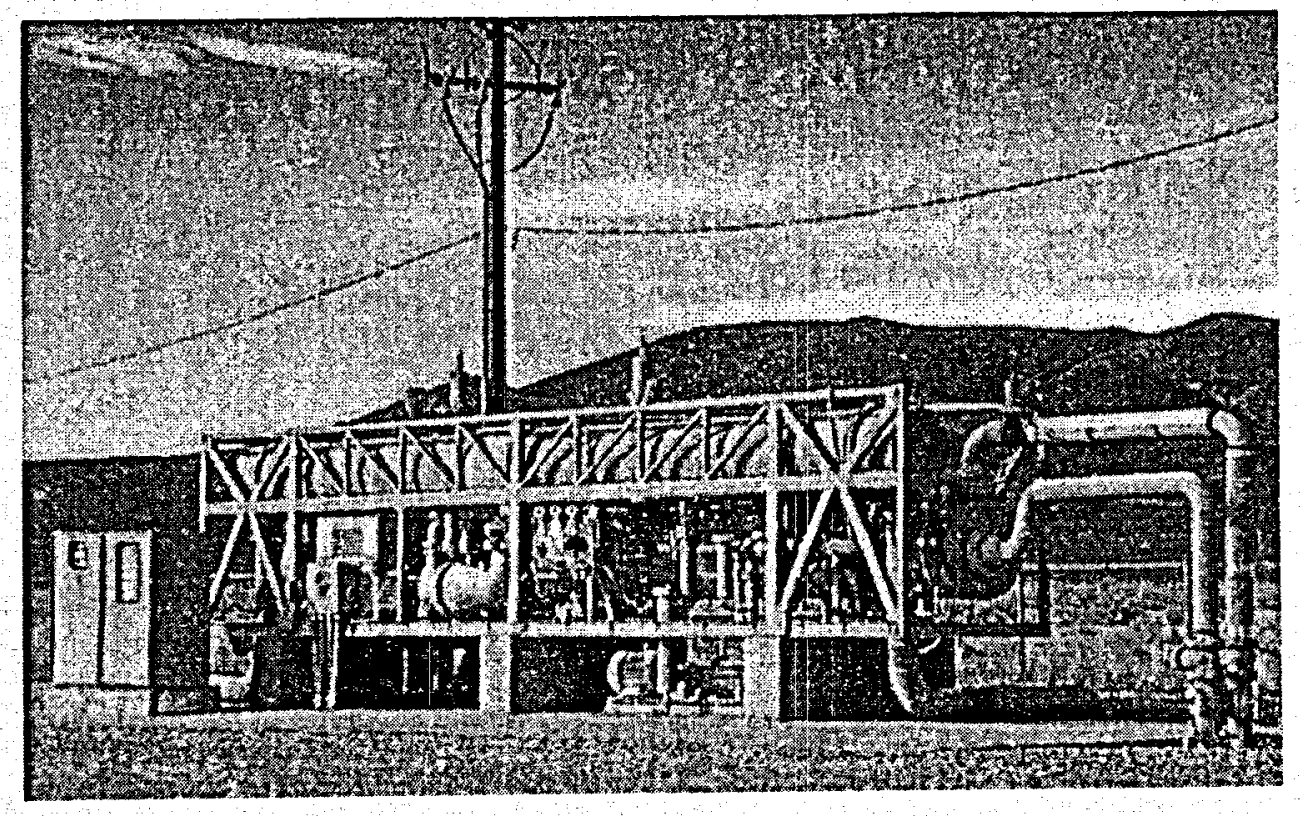




\section{DISCLAIMER}

This report was prepared as an account of work sponsored by an agency of the United States Government. Neither the United States Government nor any agency Thereof, nor any of their employees, makes any warranty, express or implied, or assumes any legal liability or responsibility for the accuracy, completeness, or usefulness of any information, apparatus, product, or process disclosed, or represents that its use would not infringe privately owned rights. Reference herein to any specific commercial product, process, or service by trade name, trademark, manufacturer, or otherwise does not necessarily constitute or imply its endorsement, recommendation, or favoring by the United States Government or any agency thereof. The views and opinions of authors expressed herein do not necessarily state or reflect those of the United States Government or any agency thereof. 


\section{DISCLAIMER}

Portions of this document may be illegible in electronic image products. Images are produced from the best available original document. 


\title{
SMALL GEOTHERMAL ELECTRIC SYSTEMS FOR REMOTE POWERING
}

\author{
August 8, 1994 \\ By: \\ Daniel J. Entingh (1), Eyob Easwaran (1), and Lynn McLarty (2) \\ (1) Princeton Economic Research, Inc., Rockville, MD \\ (2) DynCorp-Meridian, Alexandria, VA
}

For:

The Geothermal Division, U.S. Department of Energy, Washington, D.C. 


\section{ABSTRACT}

This report describes conditions and costs at which quite small ( 100 to 1,000 kilowatt) geothermal systems could be used for off-grid powering at remote locations. This is a first step in a larger process of determining locations and conditions at which markets for such systems could be developed.

The results suggest that small geothermal systems offer substantial economic and environmental advantages for powering off-grid towns and villages. Geothermal power is most likely to be economic if the system size is $300 \mathrm{~kW}$ or greater, down to reservoir temperatures of $100^{\circ} \mathrm{C}$. For system sizes smaller than $300 \mathrm{~kW}$, the economics can be favorable if the reservoir temperature is about $120^{\circ} \mathrm{C}$ or above. Important markets include sites remote from grids in many developing and developed countries. Estimates of geothermal resources in many developing countries are shown.

\section{Introduction}

This report concentrates on the capabilities and costs of geothermal "binary" power conversion systems because they are the most likely to be economical at geothermal reservoirs with relatively low fluid temperatures. Such geothermal resources are very common in some regions of the world. U.S. firms built about $300 \mathrm{MWe}$ of geothermal binary units in the last decade. While most of those units have capacities of 5,000 kilowatts (kW) and larger, U.S. firms have manufactured and installed binary units as small as $300 \mathrm{~kW}$. [1] Flashed-steam power plants, useful at temperatures above $150^{\circ} \mathrm{C}$, have also been constructed in small sizes. [2]

The systems described here have net capacities on the order of 100 to $1,000 \mathrm{~kW}$. They would be suitable for serving populations of 100 to 5,000 , depending on the local per-capita demand. Because these systems are smaller than the grid-connected geothermal electric systems recently built in the U.S. ( 3 to $50 \mathrm{MW}$ ), they will cost somewhat more on per-kilowatt basis. Special attention is paid here to how project costs scale to system size, and to ensuring reliability of power for portions of the load during system outages.
The report provides performance and cost estimates for a modal system of 300 kilowatt capacity working from a resource temperature of $120^{\circ} \mathrm{C}$. Effects on the cost of electricity of variations in some system parameters are shown. The purpose is to assist interested parties in making estimates of where such systems could be economically useful.

\section{System Description}

The power system gets its energy from a geothermal reservoir containing hot water. The geothermal fluid is produced through a well that is similar to an oil well. If this well is not self-flowing, is fitted with a downhole pump to increase the well flow rate and to ensure that the pressure of the water is high enough at all times to keep it from flashing into steam as it rises up the well and is piped a short distance to the power plant.

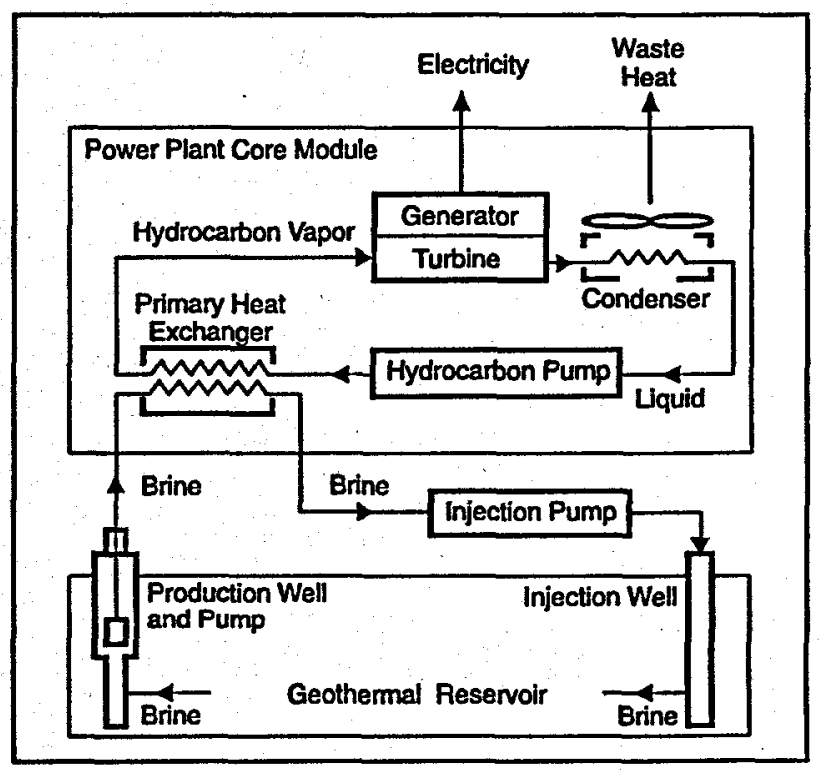

Figure 1. Schematic of an air-cooled geothermal binary electric system.

The "binary" geothermal power conversion cycle derives it name from the fact that it uses two fluids, the geothermal fluid and a working fluid with a low boiling temperature, for example, a hydrocarbon such as isopentane. In the power plant the geothermal fluid passes through a heat exchanger, where its heat is transferred to and vaporizes the working fluid. 
The heat exchanger is a long cylindrical shell with bundles of tubes inside it. The geothermal fluid passes in one direction through tubes, while the working fluid passes in the opposite direction in the shell, absorbing heat and vaporizing. From the heat exchanger, the geothermal fluid is pumped back into the ground through an injection well.

The vaporized working fluid drives the turbinegenerator. As it exits the turbine, the low-pressure vapor is liquefied in the condenser and repressurized by the hydrocarbon pump for its return to the heat exchanger. Waste heat is ejected to the atmosphere through the condenser. Because the fluids are always contained within the pipes, turbine, heat exchanger, or condenser, the system releases essentially no gases to the atmosphere.

Typically, the small systems described here will require only one production well and one injection well (or other means of brine disposal). The flow rate of geothermal fluid required by the plant decreases with increasing fluid temperature and increases with increasing power plant size. If either the resource temperature or well flow rates are relatively low, then plants of capacities on the order of $500 \mathrm{~kW}$ or greater may require two production wells.

\section{Special Features}

Some features of the technology are described here.

1. The plants are very transportable. For 100 to $300 \mathrm{~kW}$ plants, the entire plant including the cooling system can be built on a single skid that fits in a standard trans-ocean shipping container.

2. Binary power plants can accommodate a wide range of geothermal reservoir temperatures, 100 to $150^{\circ} \mathrm{C}$. (Above $150^{\circ} \mathrm{C}$, flashed-steam plants are usually less expensive.) The conversion efficiency is quite low at the lower temperatures, and therefore the cost of power becomes higher. Reservoir temperature is the physical factor to which overall project costs are most sensitive.

3. The demand for electric capacity per person at off-grid sites will range from $0.2 \mathrm{~kW}$ in lessdeveloped areas to $1.0 \mathrm{~kW}$ or higher in developed areas. A $100 \mathrm{~kW}$ plant could serve 100 to 500 people. A $1,000 \mathrm{~kW}$ plant would serve 1,000 to 5,000 people.

4. The design of the power plants and their interactions with the wells includes provisions for handling fluctuating loads, including low instantaneous loads ranging from 0 to 25 percent of the installed capacity.

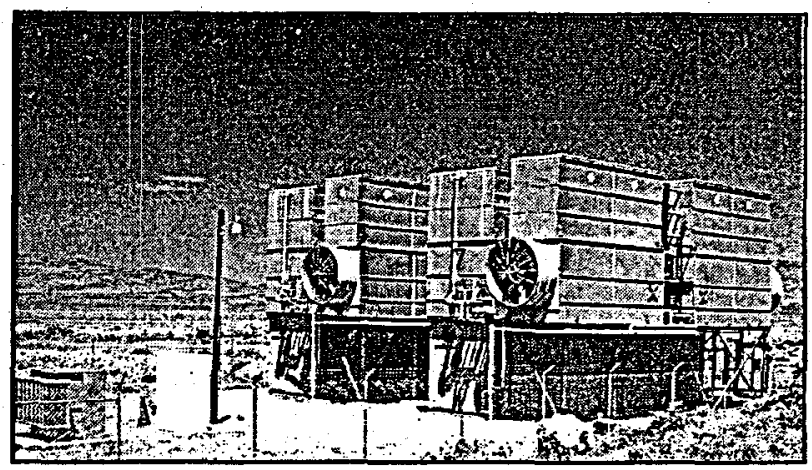

Figure 2. Barber-Nichols 2 X 350 kilowatt plant at Wineagle, California. Plant availability has been more than 98 percent since it was installed in 1985.

5. Power plant designs emphasize a high degree of computer-based automation, demonstrated successfully at the Wineagle and Wendell-Amedee plants in California. The plants are designed to be selfstarting. Only semi-skilled labor is needed to monitor plant operation, on a part-time basis. Completely unattended operation might also be possible, with plant performance monitored and controlled remotely through a satellite link.

6. The system releases no greenhouse gases $\left(\mathrm{CO}_{2}\right.$, NOx, or SOx) to the atmosphere. There may be very small leakages of the binary-cycle working fluids, but these do not contain chlorine or fluorine and are nongreenhouse gases. [3]

7. All wells would be drilled by truck-mounted rigs, either heavy-duty water-well rigs or light-duty oil/gas-well rigs. At very remote sites, both drilling rig and power system equipment can be transported by helicopter.

8. Injection well costs can be relatively low. For these small systems, because the geothermal flow rates are relatively small, there will rarely be a need to inject the fluid back into the production reservoir. 
Any shallow aquifer not used for drinking water could be used for reinjection. If the fluids are clean enough to be disposed of on the surface, then the disposal costs can be quite low.

9. Field piping costs are low. All wellheads are located near the power plant module. Inexpensive plastic or carbon steel pipe is used to connect wells.

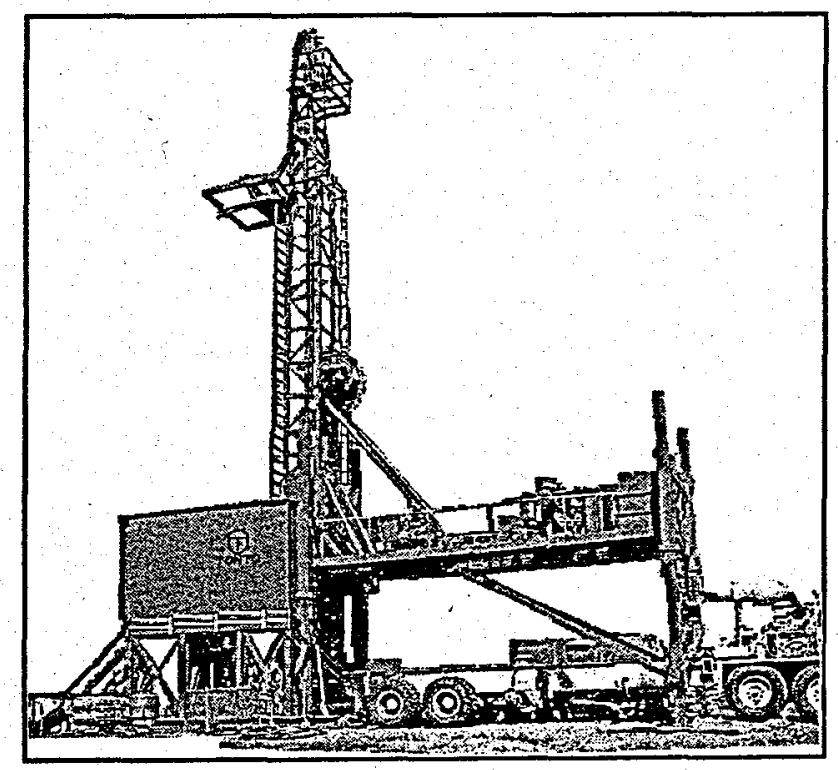

Figure 3. Truck-mounted drilling rig. Such rigs can drill to $2 \mathrm{~km}$ or more, at relatively inaccessible locations.

10. Geothermal direct heat applications can be attached to these electric systems inexpensively. Applications needing temperatures not higher than $65^{\circ} \mathrm{C}$ might be attached in series to the power-plant fluid outlet line. Some production wells will have greater flow capacity than that needed by the power plant . - part of this fluid could be used for highertemperature direct uses connected in parallel to the power plant.

11. Critical backup need is estimated to range from 1 to 5 percent of the installed geothermal capacity. The very high availability factors for geothermal systems, on the order of 98 percent, substantially reduce the cost of special features needed to ensure that power is always available. Small critical loads, e.g., medical refrigeration or pumping of drinking water, could be supported against brief unscheduled outages either by a diesel engine (that is also used for system startup) or by small amounts of battery storage. Planned outages for system maintenance, and the rare instances of longer-duration unscheduled outages, could be supported by small truck-mounted diesel generators. One such truck would be able to service 5 to 30 small geothermal units.

\section{Cost and Performance Details}

Some aspects of system design and cost estimates are described here. Details about performance and costs are provided in the Appendix. The details there can provide insights about how these systems can be configured to optimize certain aspects of costs.

Many of the inputs and results shown here are defined for a "modal" system that assumes a $300 \mathrm{~kW}$ power plant installed at a $120^{\circ} \mathrm{C}$ geothermal reservoir.

Power Plant Core Module: Estimates of the cost and performance of small binary power plants form the most critical and novel part of this analysis. The detailed estimates used here were provided by Ken Nichols, of Barber-Nichols Inc., Arvada, Colorado, a manufacturer of small binary units. The estimates have been reviewed by Dan Schochet, of ORMAT, Inc., Sparks, Nevada (another manufacturer of such units) and found to be reasonable for U:S. installations.

The Flashed-Steam Alternative: Geothermal Power Company, Elmira, New York, has built and installed a number of small noncondensing flashed-steam power plants, sized between 500 and $1,000 \mathrm{~kW}$. [2] No cooling system is needed. The plants are mounted on a single skid and are very easy to install. These plants are generally more economical than binary plants when steam of $150^{\circ} \mathrm{C}$ or higher can be produced from geothermal wells.

\section{Features to Ensure System Reliability}

The systems described here are envisioned as not being connected to a power grid. Therefore, certain items have been added to the general design and cost estimates to ensure that the system can follow relatively low instantaneous loads and that critical loads can be maintained during brief periods of unplanned and planned system outage. These items are representative of what might be included, and 
would not necessarily be prescribed for every system.

Low Load Factors: U.S. geothermal electric systems are designed to work at high constant throughput. Costs have been added to the estimates made here to account for design features and equipment needed to allow these plants to follow relatively low instantaneous loads in non-grid applications. Further details will have to be developed for the exact means by which these systems would support low partial loads. It is likely that three levels of features would be involved: (a) Simple throttling of the turbine in the load range of 50 to 100 percent, with brine flow relatively unabated; (b) Some production well throttling, plant bypass valves, and a brine surge tank added to the system, to accommodate the load range of 10 to 50 percent; (c) Shedding power into a dissipative resistive load to accommodate loads in the range of 0 to 10 percent.

Cold-Start Power: These plants may require some electrical power to start them from cold conditions. If the geothermal well flow is artesian, then the plant will self-start once the primary heat exchanger is warmed up. Under other conditions, 5 to 10 percent of the plant's nominal capacity may be needed to start the plant. The systems costed here include a selfstarting diesel-generator. This diesel would also serve as the backup power for small critical loads.

Battery Storage: If additional critical backup power is needed, it could be furnished from battery storage. Cost estimation factors are included in the Appendix. The "modal" geothermal power system described and costed here does not include battery storage.

Diesel Truck Backup: Truck-mounted diesel generators could be used to back up these plants during brief periods of scheduled maintenance and other brief outages. In many instances, a number of these small plants in a region would be served by one truck, with a relatively low overall cost per geothermal system. At many sites, the diesel truck would have to supply only certain "semi-critical" loads during this servicing period.

\section{System Capacity Factor}

The capacity factor (CF, system annual utilization factor) has a strong impact on any capital-intensive project. The cost of power values shown in this report assume CF's of 0.80 , typical of U.S. gridconnected geothermal plants. Off-grid applications might see this reduced to as low as 0.30 , especially during the initial few years of operation at sites where the geothermal system provides the first substantial electricity to a market. Cost of electricity will be inversely proportional to the $\mathrm{CF}$ actually experienced. E.g., for a CF 0.50 , the cost of power will be $8 / 5$ times that estimated for a CF of 0.80 .

\section{Cost of Power Results}

Parameters and costs for the modal system are shown in Tables 1 and 2.

\begin{tabular}{||l|r||}
\hline Table 1. Specifications of Modal System \\
\hline \hline Resource Temperature, ${ }^{\circ} \mathrm{C}:$ & 120 \\
System Net Capacity, $\mathrm{kW}:$ & 300 \\
Plant Flow Need, $\mathrm{kg} / \mathrm{kWh}:$ & 235 \\
& \\
Number of Wells: & 2 \\
Production Well Flow, kg/hr: & 70,500 \\
Production Well Depth, $\mathrm{m}:$ & 300 \\
Production Pump Power, $\mathrm{kW}$ & 46 \\
Injection Pump Power, $\mathrm{kW}$ & 16 \\
& \\
Plant Self-Start Power, $\mathrm{kW}$ & 21 \\
Critical Backup (via batteries): & None \\
Scheduled Backup: & $50 \mathrm{~kW}$ for \\
& 7 days/year \\
Capacity Factor: & 0.80 \\
\hline
\end{tabular}

The cost of power from this system installed in the U.S., $10.5 \mathrm{c} / \mathrm{kWh}$, is quite acceptable for many remote applications. Costs outside of the U.S. might be 5 to 20 percent higher. The costs do not include expenses for local electricity distribution poles, wires, and transformers.

Useful estimates of the costs against which these geothermal systems compete come from the U.S. Department of Energy Office of Solar Energy Conversion [6]. In 1991 dollars, power from diesel generators was estimated to cost 46 to $103 \mathrm{c} / \mathrm{kWh}$, (at fuel prices ranging from $\$ 0.40$ to $\$ 1.00 /$ liter). Power from solar photovoltaic systems (including battery 


\begin{tabular}{||c|r||}
\hline Table 2. $\begin{array}{c}\text { Estimated Costs of Modal } \\
\text { System, 1993 \$ }\end{array}$ \\
\hline \hline A. Capital Costs, \$1000 & 200 \\
Exploration: & 325 \\
Wells: & 94 \\
Field, Other: & 659 \\
Power Plant: & 18 \\
Self-Start Power: & 0 \\
Backup Batteries: & 10 \\
Backup Truck: & \\
& \\
B. O\&M Costs, \$1000/Year & 32 \\
Field: & 26 \\
Plant: & 5 \\
Backup Systems: & \\
\hline Electricity Cost, (levelized & $10.5 \mathrm{c} / \mathrm{kWh}$ \\
in 1993 constant dollars): & \\
\hline
\end{tabular}

storage) was estimated to cost 75 to $100 \mathrm{c} / \mathrm{kWh}$ in 1991 , and projected to cost 34 to $60 \mathrm{c} / \mathrm{kWh}$ in 2000 . In that study, the equivalent cost of extending an electric grid was estimated to be as high as 7 to $9 \mathrm{c} / \mathrm{kWh}$ per $\mathrm{km}$ of grid for systems of low capacity. Considering those estimates, it seems likely that geothermal electricity that costs as much as $30 \mathrm{c} / \mathrm{kWh}$ could be economically attractive in many settings.

Table 3 shows effects on the cost of power of a number of variations of system conditions and configurations. The estimated cost of power for a $1,000 \mathrm{~kW}$ plant at a $140^{\circ} \mathrm{C}$ reservoir is $4.7 \mathrm{c} / \mathrm{kWh}$, very attractive under most conditions. Even if the capacity factor of that plant were as low as 30 percent, the $12.5 \mathrm{c} / \mathrm{kWh}$ cost would be acceptable in many circumstances.

Note also in Table 3 the effects on the cost of power if one or more of the geothermal wells does not have to be drilled or paid for by the projects.

\begin{tabular}{|c|c|c|}
\hline Case & Changes from Modal Case Conditions & $\begin{array}{l}\text { Cost of Power, } \\
\text { Cents/Kwh }\end{array}$ \\
\hline Modal Case & $\begin{array}{l}\text { Modal Case Conditions: }\left(120^{\circ} \mathrm{C} \text { fluid; }\right. \\
300 \mathrm{~kW} \text { capacity; } 80 \% \text { capacity factor) }\end{array}$ & 10.5 \\
\hline Hotter Geothermal Fluid & $-140^{\circ} \mathrm{C}$ fluid & 9.1 \\
\hline Larger Plant & $-1,000 \mathrm{~kW}$ capacity & 5.6 \\
\hline Lower Capacity Factor & $-40 \%$ capacity factor & 21.0 \\
\hline Hotter Geothermal Fluid and Larger Plant & $\begin{array}{l}-140^{\circ} \mathrm{C} \text { fluid } \\
-1,000 \mathrm{~kW} \text { capacity }\end{array}$ & 4.7 \\
\hline $\begin{array}{l}\text { Cooler Geothermal Fluid and Smaller } \\
\text { Plant }\end{array}$ & $\begin{array}{l}-100^{\circ} \mathrm{C} \\
-100 \mathrm{~kW} \text { capacity }\end{array}$ & 34.6 \\
\hline $\begin{array}{l}\text { Hotter Geothermal Fluid, Larger Plant, } \\
\text { and Very Low Capacity Factor }\end{array}$ & $\begin{array}{l}-140^{\circ} \mathrm{C} \text { fluid } \\
-1,000 \mathrm{~kW} \text { capacity } \\
-30 \text { percent capacity factor }\end{array}$ & 12.5 \\
\hline Artesian Flow in Production Well & - No downhole production pump & 7.8 \\
\hline Surface Disposal of Spent Brine & - Injection well not needed & 9.0 \\
\hline $\begin{array}{l}\text { Artesian-Flowing Production Well Exists } \\
\text { and Surface Disposal of Spent Brine }\end{array}$ & $\begin{array}{l}\text { - Production well capital cost }=\$ 0 \\
\text { - No downhole production pump } \\
\text { - Injection well not needed }\end{array}$ & 5.5 \\
\hline
\end{tabular}




\section{Markets for These Systems}

The market potential for these systems is large. Estimates of the geothermal resource potential, in units of MW capacity for 30 years $(1 \mathrm{MW}=1,000$ $\mathrm{kW}$, for high-temperature resources for a number of countries are shown in Table 4 [4]. The available amount of lower-temperature resource in each country will tend to be larger. The countries are grouped by regions that could be served by coordinated efforts to market, install, and maintain small geothermal systems.

The characteristics of off-grid markets for electricity service present some challenges for electricity supply decision makers and geothermal developers. The general task is to find sites where currently unsatisfied demand or rapidly growing demand for power is collocated with relatively easy-to-access geothermal resources. Another consideration is that in most cases the proposed geothermal facilities should not be situated too far from locations with some mechanicalservicing capability, to keep ordinary maintenance costs reasonable.

Situations where geothermal systems could be of economic or societal advantage include:

Substitution for diesel or other oil-fueled capacity where baseload demand is already established (e.g., small grids on some islands); (b) Indications of pentup demand in commercial, manufacturing, or mining operations; (c) Locations where geothermal can be paired with other generation options, such as hydropower or biomass [5]; and (d) Situations where it is feasible to site a new socially-necessary facility (e.g., a regional hospital or educational center) near a geothermal resource.

These systems are likely to be especially valuable in rural development programs and projects. Where geothermal resources are present, their development can provide both electricity and inexpensive crop drying through direct use of geothermal heat.

Perhaps the single most important thing that can be done to identify and define such markets is to broadcast information about the availability, performance, and costs of small geothermal electric systems to non-U.S. energy officials, rural development agencies, and entrepreneurs who are aware of locations and conditions where such systems would be useful.

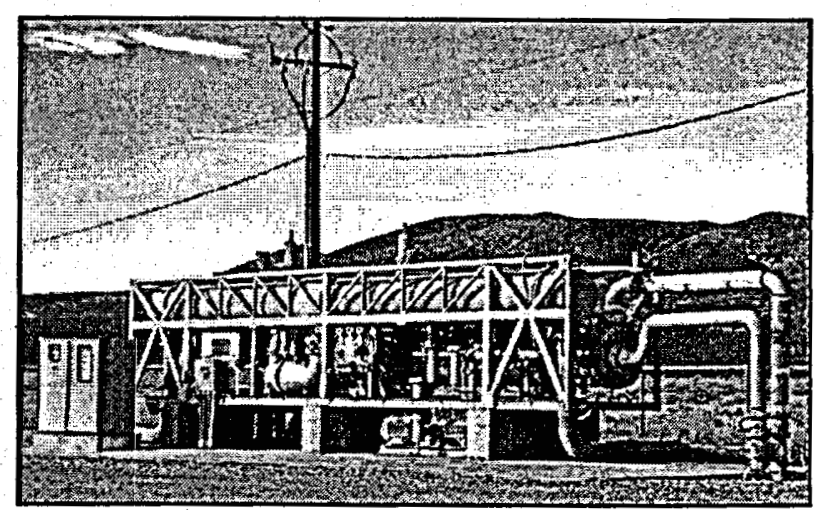

Figure 4. This $880 \mathrm{~kW}$ ORMAT unit at Wabuska, Nevada is water cooled. It was installed in 1984. 
Table 4. Potential for Geothermal Electric Power in Developing Countries (Capacity, Megawatts for 30 years)

\begin{tabular}{|c|c|c|c|c|c|c|c|}
\hline \multicolumn{2}{|c|}{ Africa, Rift Valley } & \multicolumn{2}{|l|}{ Asia } & \multicolumn{2}{|c|}{ Central America } & \multicolumn{2}{|l|}{ Pacific Islands } \\
\hline Burundi & 50 & China & 2,000 & Costa Rica & 3,500 & Fiji & 50 \\
\hline Djibouti & 500 & India & 200 & El Salvador & 2,000 & Papua N G & 300 \\
\hline Ethiopia & 5,000 & Indonesia & 16,400 & Guatemala & 4,000 & Solomon Is. & 50 \\
\hline Kenya & 3000 & Philippines & 8,000 & Honduras & 500 & Tonga & 50 \\
\hline Malawi & 50 & Taiwan & 200 & Mexico & 8,000 & Vanuatu & 40 \\
\hline Mozambique & 50 & Thailand & 100 & Nicaragua & 4,000 & & \\
\hline Rwanda & 200 & Vietnam & 100 & Panama & 200 & & \\
\hline Somalia & 50 & & & & & & \\
\hline Tanzania & 600 & & & & & & \\
\hline Uganda & 500 & \multirow{2}{*}{\multicolumn{2}{|c|}{ Caribbean Islands }} & \multirow{2}{*}{\multicolumn{2}{|c|}{ Europe }} & South Americ & \\
\hline Zambia & 50 & & & & & Argentina & 1,000 \\
\hline Africa, Othe & & Dominica & 500 & Azores & 100 & Bolivia & 1,000 \\
\hline & & Grenada & 100 & Former USSR & 4000 & Chile & 1,500 \\
\hline Comoro Is. & 50 & Monteserrat & 100 & Greece & 500 & Colombia & 1,500 \\
\hline Malagasy & 300 & Nevis - St. Kitts & 50 & Hungary & 300 & Ecuador & 1,000 \\
\hline Sudan & 300 & St. Lucia & 100 & Poland & 50 & Peru & 1,000 \\
\hline Zaire & 500 & St. Vincent & 50 & Turkey & 500 & Venezuela & 500 \\
\hline TOTAL & & & & & & & $\mathbf{7 7 , 5 0 0}$ \\
\hline
\end{tabular}


APPENDIX: Details of Cost Estimates and Assumptions

This Appendix provides details of cost estimates and assumptions. The cost factors were combined in a PC-computer model, GT-SMALL, to estimate the overall system costs and the cost of power.- Copies of the model can be obtained from Entingh [11]. Most of the inputs and results described here are defined for a "modal" system that assumes a $300 \mathrm{~kW}$ power plant installed at a $120^{\circ} \mathrm{C}$ geothermal reservoir. Costs are given in 1993 U.S. dollars. The abbreviation "\$K" means $\$ 1000$.

\section{Power Plant Core Module}

The scope of the equipment costed in Tables A-1 and A-3 is that within the "power plant core module" in Figure 1: brine-to-hydrocarbon heat exchanger, hydrocarbon circulation pump, turbine, generator, and dry cooling condenser and fans. The power consumed by those pumps and fans is accounted for within the plant core module performance values, Table A-2.

Adjustments were made to the performance and cost values in Tables A-1 and A-2. (a) Cost and power consumption of brine production pumps and injection pumps were calculated separately. (b) The values in Table A-1 are for typical grid-connected plants, running at an annual capacity factor of about 80 percent. Seven percent was added to those costs to cover modifications to these plants to allow them to follow instantaneous loads as low as 15 percent of the nominal capacity. (See further discussion below.) (c) $\$ 80 / \mathrm{kW}$ was added to cover the costs of a power transformer and relay equipment.

\begin{tabular}{||l|r|r|r|}
\hline \hline Table A-1. Power Plant Capital Cost, $\$ / \mathrm{kW}$ \\
\hline \multirow{2}{*}{$\begin{array}{l}\text { Power Module } \\
\text { Net Size, kWe }\end{array}$} & \multicolumn{3}{|c|}{ Plant Inlet Temperature, ${ }^{\circ} \mathrm{C}$} \\
\cline { 2 - 4 } & 100 & 120 & 140 \\
\hline 100 & 2535 & 2210 & 2015 \\
\hline 200 & 2340 & 2040 & 1860 \\
\hline 500 & 2145 & 1870 & 1705 \\
\hline 1000 & 1950 & 1700 & 1550 \\
\hline
\end{tabular}

\begin{tabular}{|l|r|r|r||}
\hline \hline \multirow{4}{|c|}{ Table A-2. } & \multicolumn{3}{c|}{$\begin{array}{l}\text { Power Plant Brine Flow } \\
\text { Requirement, } 1000 \mathrm{~kg} / \mathrm{hr}\end{array}$} \\
\hline \multirow{2}{*}{$\begin{array}{l}\text { Power Module } \\
\text { Net Size, kWe }\end{array}$} & \multicolumn{3}{|c|}{ Plant Inlet Temperature, ${ }^{\circ} \mathrm{C}$} \\
\cline { 2 - 4 } & 100 & 120 & 140 \\
\hline 100 & 50 & 24 & 14 \\
\hline 200 & 100 & 47 & 27 \\
\hline 500 & 227 & 111 & 65 \\
\hline 1000 & 456 & 227 & 130 \\
\hline
\end{tabular}

\begin{tabular}{||c|c|c|c|c|}
\hline \hline \multicolumn{5}{|c|}{ Table A-3. Power Plant O\&M Requirements } \\
\hline \hline Plant Size, kWe: & 100 & 200 & 500 & 1000 \\
\hline $\begin{array}{c}\text { Operator-Monitor } \\
\text { (hr/yr) }\end{array}$ & 300 & 400 & 500 & 800 \\
\hline $\begin{array}{l}\text { Maintenance } \\
\text { (hr/yr) }\end{array}$ & 200 & 250 & 300 & 400 \\
\hline $\begin{array}{l}\text { Working Fluid } \\
\text { (\$/yr) }\end{array}$ & 200 & 400 & 850 & 1200 \\
\hline $\begin{array}{l}\text { Maintenance Parts } \\
(\$ / y r)\end{array}$ & 400 & 500 & 600 & 800 \\
\hline
\end{tabular}

The fully loaded cost for O\&M labor in the U.S. in 1993 was about $\$ 25 / \mathrm{hr}$ for the operator-monitor, and about $\$ 55 / \mathrm{hr}$ for skilled maintenance workers.

\section{Features to Ensure System Reliability}

Cost estimates for special items to ensure very high reliability for off-grid systems are documented here.

Low Load Factors: A "Lowest Instantaneous Load Factor" (LILF) was defined here to account for costs incurred to allow these plants to follow relatively low instantaneous loads in non-grid applications. The LILF implies a multiplier applied to the power plant core module capital cost. Our initial rough estimates of the multipliers, against the base cost of the core power module, are $1.20,1.07$, and 1.05 for LILF's of 0,15 , and 25 percent, respectively. 
Cold-Start Power: The systems costed here include a self-starting diesel-generator, sized at 7 percent of the capacity of the plant core module. This adds about 1.3 percent to the capital cost.

Battery Storage: Costs for battery storage are estimated as follows. The longest duration needed is 7 days, time enough to move a diesel truck to the location for longer backup. Utility-grade lead-acid batteries cost about $\$ 150$ per $\mathrm{kWh}$ of storage. The capacity factor (CF) for critical loads for use of this critical storage is estimated to be 0.25 . For a $10 \mathrm{~kW}$ peak battery storage system, 7 days X 24 hours/day $\mathrm{X} 0.25$ (CF) X $10 \mathrm{~kW}=420 \mathrm{kWh}$ of storage need, and the battery cost $=420 \times 150=\$ 63 \mathrm{~K}$. The balance of system costs (inverters, structural supports, wiring), at $\$ 500$ per $\mathrm{kW}$, is $\$ 5 \mathrm{~K}$. The total capital cost is $\$ 68 \mathrm{~K}$. The O\&M costs for this subsystem are essentially nil. [7] The modal system described in this report does not include battery storage.

Diesel Truck Backup: We estimate that a $50 \mathrm{~kW}$ diesel-generator truck would cost no more than $\$ 100 \mathrm{~K}$ and that $\$ 5 \mathrm{~K}$ would cover operating this for one week of scheduled maintenance at each site. The cost estimates here assume that one such truck would serve about ten small plants in a region, resulting in a $\$ 10 \mathrm{~K}$ initial capital cost per geothermal system for this aspect of backup power.

\section{Other Estimates and Assumptions}

1. Exploration Cost: The cost to discover the local geothermal resource cannot be ignored. The estimate of $\$ 200 \mathrm{~K}$ assumes an organized regional approach to exploration and test drilling, so that each stand-alone system does not bear all of the risk of exploration failure at any particular site.

2. Casing Plan: The casing plan for the two 1000foot production wells at the $100^{\circ} \mathrm{C}, 1,000 \mathrm{~kW}$ plant at Wendell-Amedee, California is: $34.6 \mathrm{~cm}$ (13 5/8 inch) O.D. to 750 feet, then $24.4 \mathrm{~cm}$ ( $95 / 8$ inch) O.D. to 1000 feet $[9$, Meidav]. The production well should, in general, be sized to allow setting a lineshaft brine production pump at about 600 feet. Available pumps require a casing I.D. of about 31.8 cm (12 1/2 inch).

3. Well Costs: Costs are estimated to be: $\$ 650$ per meter for wells up to $500 \mathrm{~m}$ deep; $\$ 800 / \mathrm{m}$ for wells 500 to $1000 \mathrm{~m}$ deep; and $\$ 1,000 / \mathrm{m}$ for total depths greater than $1000 \mathrm{~m}$. The production well for the modal system is set at 300 meters (984 feet) and costs $\$ 195 \mathrm{~K}$. One production well will generally be sufficient, unless the design entails both low reservoir temperature and "high" (e.g., 1,000 kW) power plant capacity. The modal injection well is set at $200 \mathrm{~m}$ (656 feet) deep and thus costs $\$ 130 \mathrm{~K}$. This well is assumed to inject fluid in a "disposal" manner into an aquifer that lies above the geothermal reservoir. Wells are assumed to have 30 year lifetimes.

4. Field Piping Cost: a. Production Wells: It is assumed that the power plant is located very near the wellhead, and that $\$ 10 \mathrm{~K}$ will cover hookup costs. b. Injection wells: These will be located within 500 feet of the power plant; the pipe will cost about $\$ 25 \mathrm{~K}$.

5. Geothermal Fluid Pumps: The cost of the fluid pumps is included in the cost estimate for the field. Costs were estimated from background literature and interviews [9, Frost]. Note that variable-speed motors are sometimes used on these pumps to help the plant follow varying loads. a. Downhole Production Pump: The pump is sized to produce a pressure boost of 200 psi plus other losses equivalent to about $30 \mathrm{psi}$. Power consumption is estimated from a standard flow times pressure boost equation, with an overall pumping efficiency of 70 percent. The nominal pump is expected to cost about $\$ 70 \mathrm{~K}$, but at some low flow rates the cost might be as low as $\$ 40 \mathrm{~K}$. This pump would be overhauled at roughly 2-year intervals. b. Brine Injection Pump: An 80 psi pressure boost from this pump is assumed, at an overall efficiency of 75 percent. The cost of pump with motor is estimated to be $\$ 580$ per motor horsepower.

7. Pumping Power Requirements: The estimated power (kW) needed for the brine production and injection pumps is subtracted from the net output of the power plant core module. In precise terms, this means that the actual net output of the systems will be about 5 to 15 percent lower than indicated by the nominal net output shown in the Tables, but the estimated cost of power accounts for these losses.

8. Surface Disposal Cost: Disposing the brine to the surface is included as an option in the GTSMALL model. If the number of injection wells is 
set to zero, the model sets the brine disposal cost to $\$ 50 \mathrm{~K}$ to cover the cost of disposal gutters, ditches, etc. In addition, the following terms are set to zero: Injection well cost, injection piping cost, brine injection pump cost, and brine injection pump power. This reduces the cost of power for the modal system by about 14 percent, a large saving if surface disposal is acceptable from an environmental point of view.

9. Field O\&M: The field annual O\&M cost is set at 4 percent of total field capital cost (excluding costs of exploration and of production pumps). For the modal case system, this is about $\$ 18 \mathrm{~K}$ per year. This is reasonable, since the reservoir temperatures and concentrations of dissolved minerals are relatively low compared to some geothermal systems for which general O\&M requirements are a somewhat higher percentage per year (e.g., 6 to 7 percent). Additional costs for refurbishing the downhole production pumps are calculated separately.

10. Cooling Systems: The costing here assumes dry cooling systems integrated into the power plant module. When dry-bulb temperatures exceed about 27 ${ }^{\circ} \mathrm{C}$, the net power output from a dry-cooled system will be reduced. At sites where this occurs for a high fraction of the year, evaporative (wet) cooling is more appropriate. Capital costs will be slightly less for wet-cooled systems, but on-site erection of the cooling towers will be required. Other useful cooling methods, depending on site conditions, include direct cooling from surface water or cooling ponds.

11. Flashed-Steam Alternative: Geothermal Power Company has indicated that noncondensing flashedsteam power plants, sized between 500 and $1,000 \mathrm{~kW}$, can be installed for about $\$ 1350$ per $\mathrm{kW}$. [2]

12. Economics Assumptions: Costs are shown in mid-1993 dollars. The cost of power (cents/kWh) is calculated usitig levelized revenue requirements equations. The assumptions used are those employed in recent U.S. Department of Energy analyses. [8] The nominal discount rate is 11.0 percent. The assumed rate of future inflation is 3.9 percent. The project life is assumed to be 30 years. Taxes, tax incentives, and royalties are ignored. The consequent current-dollar annual fixed charge rate for capital items is 11.67 percent. The O\&M cost levelization factor (for the 30 year project life and stated inflation rate) is 1.453. The equivalent constant-dollar annual fixed charge rate is 8.03 percent. Interest during construction is set at 8 percent of the capital costs. These assumptions are reasonable for funding of project development through national utilities. Private financing would increase the cost of funds somewhat.

\section{Cost Sensitivities}

Table A-4 shows effects on electricity cost of certain variations in system parameters. The values will allow readers to make rough estimates of the cost of power for locations where geothermal resource conditions are known. The values shown there are relative to the 10.7 cents $/ \mathrm{kWh}$ cost of power estimated for the "modal" system.

For example, for a system where the reservoir temperature is $130^{\circ} \mathrm{C}$ (the multiplier from Table $\mathrm{A}-4$ is 0.90 ) and the system net capacity is $200 \mathrm{~kW}$ (the multiplier is 1.30 ) the estimated cost of power would be: $10.7 \times 0.90 \times 1.30=12.5$ cents $/ \mathrm{kWh}$. 


\begin{tabular}{|c|c|c|c|c|c|c|}
\hline $\begin{array}{r}\text { ole A-4. Effects } \\
\text { (Ratic } \\
\text { moda) }\end{array}$ & $\begin{array}{l}\text { Cost of Po } \\
\text { cost of po } \\
\text { ystem are s }\end{array}$ & $\begin{array}{l}\text { of } \\
\text { fror } \\
\text { led.) }\end{array}$ & odal & tem. & les & le \\
\hline 1. Power Plant Net & Value: & 100 & 200 & $310 \%$ & 500 & 1000 \\
\hline & Multiplier: & 2.16 & 1.30 & (1: & 0.76 & 0.56 \\
\hline 2. Geothermal & Value: & 100 & 110 & $\sqrt{2}$ & 130 & 140 \\
\hline Temperature, ${ }^{\circ} \mathrm{C}$ : & Multiplier: & 1.53 & 1.17 & -4: & 0.90 & 0.83 \\
\hline 3. Production Well & Value: & & 200 & 310 & 500 & 1000 \\
\hline Depun & Multiplier: & & 0.95 & 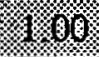 & 1.10 & 1.44 \\
\hline 4. Injection Well & Value: & [a] 0 & & 201 & 300 & 500 \\
\hline on, meters. & Multiplier: & 0.86 & & 2 & 1.04 & 1.12 \\
\hline $\begin{array}{l}\text { The } 0 \\
\text { geothe }\end{array}$ & $\begin{array}{l}\text { injectior } \\
\text { fluid is to }\end{array}$ & 1 & un & ispe & the & \\
\hline
\end{tabular}


[1] Firms with experience in the design and/or construction of small binary or binary-like geothermal power plants include: Barbêt/Nichols, Arvada, Colorado; Ormat, Inc., Sparks, Nevada; Ben Holt Company, Pasadena, California; Exergy, Inc., Hayward, California.

[2] Firms with design and/or construction expertise for small flashed steam plants include: Ben Holt Company, Pasadena, California; Geothermal Power Company, Elmira, New York; Douglas Energy Systems, Placentia, California.

[3] See P.M. Wright, Geothermal Resources Council Transactions, 1993, page 537, for estimates of emissions from geothermal electric plants.

[4] Geothermal Resource Potential, brochure of the U.S. National Geothermal Association, March 1993.

[5] Tsvi Meidav and Joshua Meidav, "Renewable Energy Development in Frontier Areas," International Conference on Regional Development. Ben Gurion University, Beer Sheva, Israel, December 1993.

[6] Solar 2000. A Collaborative Strategy, Volume 1, Figure 8, U.S. Dept. of Energy, February 1992.

[7] Estimates for battery storage costs were drawn from the Electric Power Research Institute Technical Assessment Guide (Supply, 1986) and the California Energy Commission Energy Technology Characterizations, 1990.

[8] U.S. Department of Energy, Energy Information Administration, report Annual Energy Outlook 1993.

[9] The authors are indebted to the following for various details of system performance and cost, and reviews of earlier drafts of this report: Jack Frost, Frost Consulting, Upland, CA; Ben Holt, The Ben Holt Company, Pasadena, CA; Ken Nichols, BarberNichols Inc., Arvada, CO; Dan Schochet, ORMAT Inc., Sparks, NV; Tsvi Meidav, Trans-Pacific Geothermal, Oakland, CA.

[10] This work was supported by Sandia National Laboratories contract AG-2384 to NOVA Analytics, Falls Church, VA, and Department of Energy contract AC01-93CE353060 to Princeton Economic
Research, Inc., Rockville, MD. A version of this paper was presented at the U.S. Department of Energy Conference "Geothermal Program Review XII," San Francisco, April 28, 1994.

[11] For more information, contact:

Dr. Daniel Entingh, Princeton Economic Research, Inc., 1700 Rockville Pike, Suite 550, Rockville, MD 20852 (Phone: 301-881-0650, Fax: 301-2301232);

Dr. David Lombard, Geothermal Division, U.S. Department of Energy, Washington, DC, 20585 (Phone: 202-586-4952, Fax: 202-586-5124); or

David Anderson, Executive Director, Geothermal Resources Council, 2001 2nd Street, Suite 5, Davis, CA 95616. (Phone: 916-758-2839, Fax: 916-7582839)

Notice:

This report was prepared as an account of work sponsored by an agency of the United States Government. Neither the United States nor any agency thereof, makes any warranty, express or implied, or assumes any legal liability or responsibility for the accuracy, completeness, or usefulness of any information, apparatus, product, or process disclosed. Reference herein to any specific commercial product, process, or service does not imply its endorsement, recommendation, or favoring by the United States government to the exclusion of others that may be suitable. Cost estimates herein do not imply offers of sales of equipment or services at those prices. The views and opinions of authors expressed herein do not necessarily state or reflect those of the United States Government or any agency thereof.

File: [GTSMAL-3.GTD] $8 / 8 / 94$ 